EVANS'S STONE IMPLEMENTS OF GREAT $B R I T A I N^{*}$

TJ HEN Shakespeare represented his philosophical W Duke, as finding "sermons in stones," and "books in the running brooks," he was but unconsciously exhibiting the prophetic faculty which has been attributed to all true poets. He could hardly have foreseen that his pretty yet fanciful conceit would one day be found to be sober earnest. But so it is; we have here a goodly volume of more than six hundred pages, illustrated by nearly as many excellent woodcuts, discoursing learnedly of nothing save stones and streams, and finding in them sermons of great and, to many readers, novel interest.

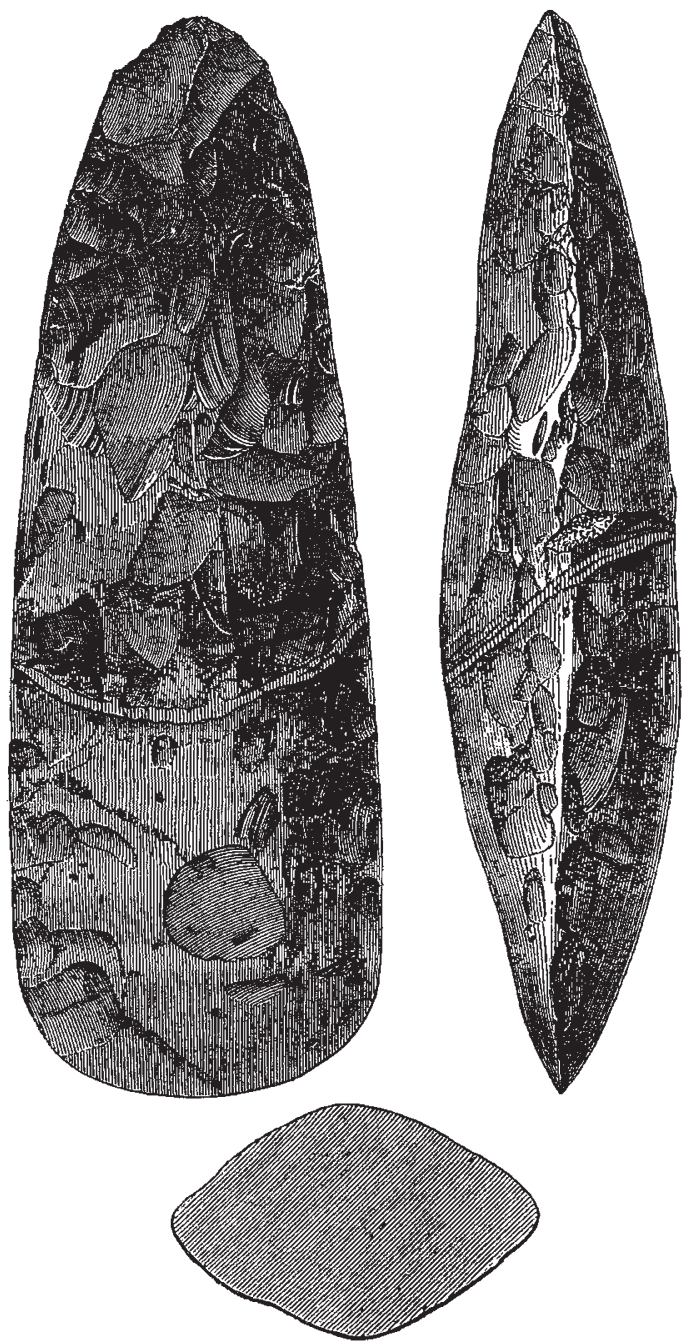

Fig. I.-Polished Celts, Santon Downham, Suffolk

It might have been supposed, when Mr. Evans had published his well-known work on "The Coins of the Ancient Britons," that he had gone back as far as possible in the history of our land and nation ; but in archreological as in other sciences, there is in the lowest known depth one lower still remaining to be fathomed; every chamber opened to the light discloses others lying beyond it. From a people who had no literature, or none of which they have left any trace beyond the rude characters inscribed on their rude coins, we are now carried back to

* "The Ancient Stone Implements, Weapons, and Ornaments of Great Britain." By Jotu Evans, F R.S., F.S.A. (London: Longmans and Co., r872.) tribes and races which possessed neither coins nor letters; people who have left us neither their sepulchres nor their ashes, nor indeed any trace of their existence, save the rude triangular or subtriangular fragments of worked stone which served them for tools or weapons; and even these are usually found buried beneath the wreck and ruin, it may be, of continents or islands which have long since been worn and wasted away.

The publication of this work is remarkable as an evidence of the quickened pace which characterises scientific research in our days. Palæontology and Geology, vigorous and flourishing as they are, are still hardly "out of their 'teens ;" but Prehistoric Archæology has made comparatively more rapid progress than either. Not more than fourteen years have passed since the discoveries made by Boucher de Perthes of flint implements in the gravel beds of Abbeville and Amiens, although at that time discredited and disparaged by the geologists of his own country, were confirmed and supplemented by $\mathrm{Mr}$. Prestwich and $\mathrm{Mr}$. Evans. Previously to that time these objects had attracted but little notice ; the things were "neither rich nor rare ;" men looked at them and wondered, and then forgot them, just as before William Smith's time they gazed with a profitless curiosity on fossil shells and bones, and thought with Dr. Martin Lister, that they might be "the efforts of some plastic power, in the earth, being the regular workings of Nature, whereby she sometimes seems to sport and play, and make little flourishes and imitations of things, to set off and embellish her more useful structures."

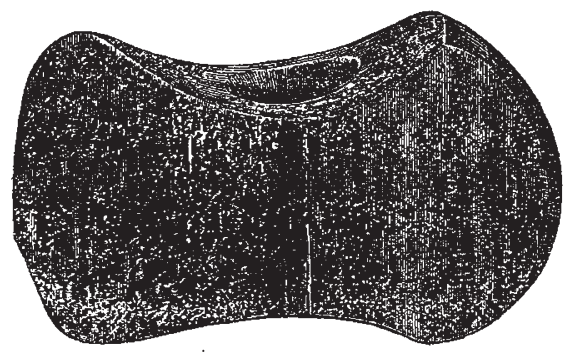

Fig. 2,-Axe-Hamer, Thames, London

But since the discoveries in the Somme Valley were recognised, a flood of light has been shed upon the subject. These dry bones live, and these rude stones are found to be useful, indeed indispensable, materials for building up the earliest history of the human race. The savans of every country in Europe have hastened to take part in an inquiry so novel and so interesting; many volumes of memoirs have been written ; our French neighbours, with their usual vivacity, have established a journal devoted to Prehistoric Archæology, as well as an annual Congrés; and these researches having been for several years conducted by so many able and eager observers, we need not wonder that Mr. Evans, having studied the whole bibliography of the subject both ancient and modern, and explored every considerable museum or collection, is now enabled to produce this Encyclopædia of the new-born science, which for want of a better word may, perhaps, be called Petrology or Petro-tomology. He has introduced us into the workshops and armouries of our most remote predecessors, it may be of our ancestors, as they existed not at any particular epoch, but in all probability through a long succession of ages; and he has shown us so clearly what were their weapons and tools, of which any vestiges remain, and how they were made and used; and has correlated them so accurately, as far as might be, with similar objects found in all quarters of the globe, as well as with those described by classical writers, or in use by modern savages, that in reading his work we know not which most to admire, the industry shown in the collection and examination of such a vast amount of material, or the skill with which the informa- 
tion thus obtained has been methodised and arranged. The book completely exhausts the subject, and will long continue to serve as a perfect manual for the collector, as well as furnishing most useful materials for archæologists and anthropologists.

Those who are not already somewhat versed in this science will be astonished to learn the infinite variety of uses to which the apparently stubborn and unmanageable rock called flint has been converted. We may, perhaps, doubt if in the very earliest ages it was used for purposes of warfare, and we prefer to give our progenitors the benefit of that doubt, and to believe that those were "golden ages"-times of primitive piety and peace ; and that it was only for purposes of husbandry, and the chase, and domestic use that they worked up the materials found in their plains and valleys. Thus, we find descriptions of celts, or axes for felling trees, or hewing canoes, hoes, threshing machines-as now used in the East-or

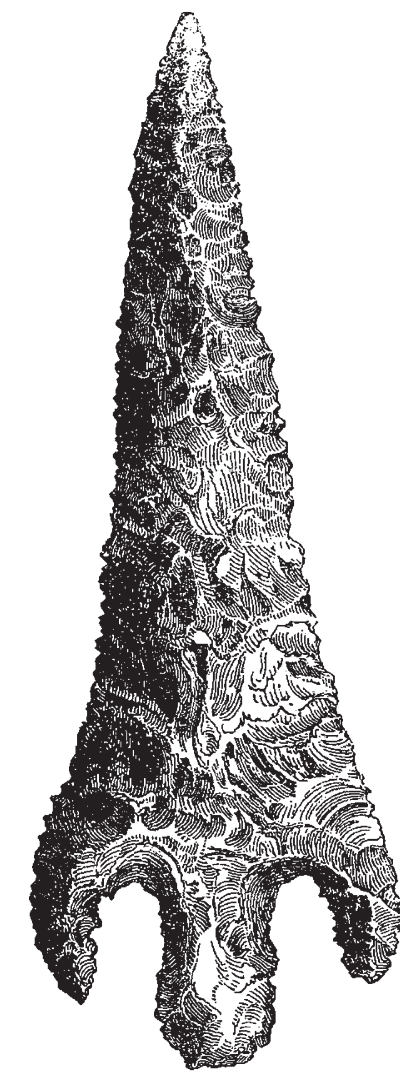

Fig. 3.-ARrow-head, Isle of SkYe

perhaps harrows, scrapers for preparing skins, arrows for birds or other "small deer," knives, gouges, saws, mullers or pounding stones, chisels, hammer axes or picks, and polishing or grinding stones, of which there must have been great need; nor were the women of the period left destitute of their share of the stony spoil ; for we find in these pages descriptions and figures of rings, armlets, amulets, spindle whorls, pestles, and, in the cave deposits, needles of bone of admirable workmanship, which might have been, and probably were, drilled by flint flakes.

As these primitive people have left us no record of their progress in arts and manufactures, and the material evidences bearing on the subject are found in a very confused and dislocated condition, it is a work of no small labour to classify and arrange them in order of date, or rather of sequence, and thus none but a rough and wide scheme of classification is possible. The Danish and French authors, as well as many of our own, usually divide the stone implement period into two principal stages only, the Palæolithic and Neolithic-unpolished and polished; placing them both before what has been called the Bronze age. This arrangement, however, although found convenient for popular use, and in that sense adopted by $\mathrm{Mr}$. Evans, can hardly be regarded as scientifically accurate; as he has himself observed, there are blanks in the chronology of stone implements, which it is hard to fill up. The classification may be, and indeed is, too wide in one respect, and tos limited in another. Whilst, on the

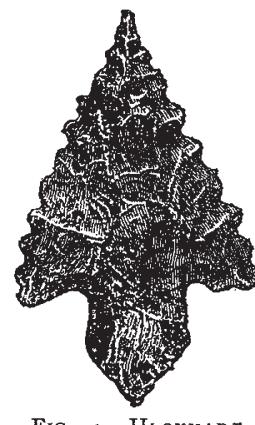

one hand, the drift and the cave implement periods, which are usually bracketed together as Palæolithic, are characterised by very various conditions, both palæontological and geological, and, indeed, technological also-conditions which may indicate their separation by a vast interval of time; so, on the other hand, as Mr. F.vans has shown at the close of the fourth chapter, some of the unpolished stones, chipped or rough hewn celts, were probably of a date not earlier than some that were ground and polished; and, in Great Britain, at least, there are not wanting indications that the use of bronze was coeval with the polished stone period, if not, indeed, with one or two exceptions (which were probably imports) anterior to it.

One of the most perplexing questions sugrested by the discovery of the drift implements relates to the means by which they came into their present position. They are often met with at a depth of twenty or even thirty feet,

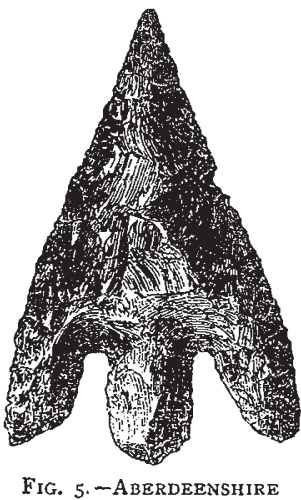

usually at or near the base of thick beds of coarse flint gravel, which in its turn is overlain by masses, more or less thick, of brick-earth or loess. Occasionally, and indeed not rarely, they occur entirely beneath the gravels, and on the surface of the subjacent rock, whatever it may chance to be. Mr. Evans deals with them merely as constituent portions of the beds of sand, gravel, and clay, in which they occur, and so indeed they now are, but they are something more. Although of the drift, drifty, each has its own separate history; for each has been held and fashioned by hands guided by an intelligent will, and thus 
we are led irresistibly to inquire when, and why, and how did they come where we now see them, and why are they never found on the surface, nor under any other conditions?

To a certain extent this inquiry is involved in the far larger question of the forces by means of which the superficial gravels, of which the implements are as it were but the accidents, became dispersed-a subject which does not necessarily come within the scope of a work designed to be technological rather than geological. Mr. Evans has, however, very judiciously devoted one of his chapters to i and as it is one of great interest, and is still involved in much obscurity, we may gladly welcome any attempt to deal with it, especially by one who has given so much attention to its investigation.

It was the oplinion of the late Dr. Buckland, an opinion which was concurred in by Greenough, Conybeare, and other able writers of their time, that the general dispersion of gravel, sand, and loam, over hills and elevated plains, as well as valleys, was the result of a universal deluge, which is described as transient, simultaneous, and of a date not very remote ; that the existing system of valleys was mainly due to the same cause, and that thus both valleys and gravels preceded our present river systems. Cuvier, and the French geologists generally, have held the same opinion, but of late years it seems to have been altogether discredited by English authors, with perhaps the exception of the late Sir Roderick Murchison. We may well entertain doubts as to the occurrence of a deluge that should be both universal and simultaneous; and it is probable that it is chiefly on that account that Dr. Buckland's theory has met with so little favour, Still, although we may be unable to adopt his views in their entirety, his statements as to the diluvial characters of the English drifts seem entitled to some further consideration before they are set aside altogether, and on this account it is fortunate that the recent discoveries of flint implements have excited so much interest in the gravels in question as to induce Mr. Evans to devote no inconsiderable portion of his work to the history and antiquity of the River drift.

In the last chapter he has adduced an elaborate argument in favour of the belief in fluviatile transport as opposed to diluvial, by showing first hypothetically the possibility that "deposits now occupying the summits of hills have originally been formed in and about river beds," and then, by reference to the actual phenomena, the probability that the implement-bearing beds were thus formed. No one can doubt, upon the hypothesis here stated, that rivers may have possessed at one time a far greater power of excavating and deepening their channels than now; but then the author is obliged to assume the prevalence of several conditions, and notably a far more rigorous climate, and a greater amount of rainfall ; conditions as to which we have but little evidence, and some of that is of a doubtful tendency. If, as is now supposed, the hippopotamus and elephant and rhinoceros remained here all the winter, they would have fared but badly, had the climate been as severe as is supposed.

But passing by these topics as not bearing very immediately upon the question of transport, it cannot be doubted that submergence, by means of diluvial action, is quite possible, since we have many instances of it within the historical period, and some indeed within the last few years; and both modes of transport being alike possible, the probabilities of the case have alone to be considered; and, notwithstanding the various reasons so ably stated by Mr. Evans, it does not seem that there are sufficient grounds for rejecting Dr. Buckland's theory, and there are besides some inferences to be drawn from the position of the implements which, so far as they are concerned, are at variance with the theory of fluviatile transport. For instance, when met with in valleys, it appears that the implements are not found along the whole course of those valleys, as well where flint gravels are wanting, as where they abound, as would have been the case had they been carried down promiscuously by the streams from time to time; but, only in certain limited areas, and then usually in large numbers, and at about the same levels; and further, that in several of these deposits the implements are distinguished from those of neighbouring deposits by some slight difference in form. From these indications it may be inferred that they were made and left at or near the spots on which they are found, and afterwards covered up, and occasionally displaced, by the masses of drifted material which now overlie them; and this seems the more probable, when it is seen that some of them were formed from stones of the same kind as those composing the beds in which they rest, and that some of these appear to have lain exposed upon the surface for long periods before they were worked.

If, indeed, it had happened that these things had never been found elsewhere than in river valleys, the conclusions arrived at by Mr. Evans would have been irresistible, but so far from this being the case, it is certain that these implement-bearing gravels are occasionally found on the extreme margin of sea cliffs, or isolated hills on the verge of far-stretching plains--situations to which no river flowing in the same channels, and draining the same areas as now, could have carried them.

Mr. Evans has noticed several of these deposits as met with at Bournemouth, the Reculvers, and the Foreland cliffs in the Isle of Wight (to these probably should be added Southampton, and Brandon Down, and some others) ; and he has also alluded to the remarkable discovery in the Madras Presidency of implements of quartzite of true drift type, found on the cliffs at an elevation of three hundred feet above the sea, in a bed of ferruginous clay which forms the coast line for several hundred miles, and is intersected at right angles at various intervals, by the rivers of the country in making their way to the sea.

In all these cases all traces of the ancient rivers, if indeed they ever existed, have been entirely effaced; neither channels, nor outlets, nor adequate water-sheds, nor a single land or river shell, remaining to testify of them; and not only so, but we find many deposits of quaternary gravel (which Mr. Evans justly concludes to be of the same geological period as those of the implements, and to owe their existence and position to the same causes) on hills which could not have been reached by modern rivers. The whole country would have been a vast lake before such heights could have been submerged; and under such circumstances it may be fairly assumed that the same forces, whatever they were, that covered the hill-tops, may have partially filled up the valleys; the presence of gravel may suggest, but cannot prove, that the river brought it, however much it may have re-arranged and sorted it; both valley and gravel may have had an existtence before the river began its course. We have many valleys and gravels without rivers, and rivers without gravels; they can very well exist apart, and, doubtless, have often done so.

(To be contimued.)

\section{THE HUNTERIAN MUSEUM*}

$\mathrm{NE}$ of the most interesting features in connection with the annual election of Fellows into the Council of the Royal College of Surgeons, is the exhibition of additions about to be made to the Museum, and which have accrued since the last meeting. Prof. Flower, the Conservator, states in his Report that in the pathological collection eighty-eight additions have been made, against sixty-two during the past year, and that the microscopical characters of all recent speciniens sent to the College, and thought worthy of preservation, had been carefully described and delineated by $\mathrm{Mr}$. Goodhart, the Pathological

\footnotetext{
* Fron the Medical Times and Gazette.
} 